\title{
PENINGKATAN HASIL BELAJAR MUATAN IPA MELALUI MODEL PEMBELAJARAN PROBLEM BASED LEARNING (PBL) BERBANTUAN MEDIA AUDIO VISUAL DAN GAMBAR PADA SISWA KELAS 4 SDN BRINGIN 01
}

\author{
Shofi Wedhi Prayuda ${ }^{1}$, Wasitohadi2, Theresia Sri Rahayu ${ }^{3}$ \\ ${ }^{1}$ Pendidikan Guru Sekolah Dasar, Universitas Kristen Satya Wacana, shofiwedhiprayuda1@gmail.com, \\ ${ }^{2}$ Pendidikan Guru Sekolah Dasar, Universitas Kristen Satya Wacana, wasitohadi@staff.uksw.edu \\ ${ }^{3}$ Pendidikan Guru Sekolah Dasar, Universitas Kristen Satya Wacana, th.rahayu@gmail.com
}

INFO ARTIKEL
Riwayat Artikel:
Diterima: 02-04-2018
Disetujui: 17-04-2018

Kata Kunci:

Hasil Belajar, Model Pembelajaran Problem Based Learning (PBL), IPA

\section{A. LATAR BELAKANG}

Pembelajaran adalah sesuatu yang memberdayakan potensi peserta didik yang masih dirasa kurang maksimal, sehingga dalam proses pembelajaran menjadi kurang afektif. Dalam proses pembelajaran seharusnya siswa dilibatkan secara langsung didalam pembelajaran sehingga siswa dapat mengembangkan pengetahuan , daya berpikir dan kemampuannya. Dengan adanya pendidikan akan mampu memperluas pengetahuan manusia dalam membentuk nilai, sikap perilaku dan karakter seseorang itu sendiri. Pendidikan selalu berpegang teguh pada prinsip-prinsip norma dan moral, sehingga akan menjadikan manusia lebih bermoral yang terletak pada proses pembentukan karakter kepribadian setiap individu itu sendiri.

Dalam Permendikbud No 23 Tahun 2016 Pasal 1 Ayat 3, mengatakan bahwa pembelajaran adalah proses interaksi antar peserta didik, antara peserta didik dengan pendidik dan sumber belajar pada suatu lingkungan belajar. Hal ini diatur dalam Permendikbud No 22 Tahun 2016 yang berisi proses pembelajaran pada satuan pendidikan diselenggarakan secara interaktif, inspiratif, menyenangkan, menantang, memotivasi pesertadidik untuk berpartisipasi aktif, serta memberikan ruang yang cukup bagi prakarsa, kreativitas, dan kemandirian sesuai dengan bakat, minat, dan perkembangan fisik serta psikologis peserta didik. Untuk itu setiap satuan pendidikan melakukan perencanaan pembelajaran, pelaksanaan proses pembelajaran serta penilaian proses pembelajaan untuk meningkatkan efisiensi dan efektivitas ketercapaian kompetensi lulusan. Berdasarkan isi Permendikbud No.81 A Tahun 2013, tentang pembelajaran dengan menggunakan pendekatan saintifik, siswa dapat mengkontruksi kognitif bagi dirinya sendiri. Pendekatan saintifik diimplementasikan dalam kegiatan yaitu (1) mengamati berarti siswa 
mengidentifikasi hal-hal yang ingin diketahui, (2) menanya berarti siswa membuat dan mengajukan pertanyaan tentang hal-hal yang yang tidak paham dari apa yang diamati, (3) mencoba berarti siswa mengeksplorasi, mencoba dan mengumpulkan data kemudian memodivikasi untuk membuat pola dan menyimpulkan, (4) mengasosiasi berarti siswa mengolah informasi yang sudah dikumpulkan kemudian dihubungan dan disimpulkan, (5) mengomunikasikan berarti siswa menyampaikan hasil pengamatan, (6) mencipta berarti siswa mampu menginovasi berdasarkan pengetahuan yang dipelajari. Pendekatan santifik bertujuan meningkatkan kemampuan intelek, khususnya kemampuan berpikir tingkat tinggi siswa. Pembelajaran saintifik mencakup tiga ranah yaitu sikap, pengetahuan dan keterampilan. Kompetensi sikap diperoleh melalui aktivitas menerima, menjalankan, menghargai, menghayati dan mengamalkan. Keterampilan diperoleh melalui aktivitas mengamati, menanya, mencoba, menalar, menyaji, dan mencipta. Sedangkan pengetahuan diperoleh melalui aktivitas mengingat, memahami, menerapkan, menganalisis, mengevaluasi dan mencipta. Seperti yang tertulis pada permendikbud No 24 Tahun 2016 yaitu pelaksanaan pembelajaran pada Sekolah Dasar/Madrasah Ibtidaiyah (SD/MI) dilakukan dengan pendekatan tematik-terpadu, kecuali untuk mata pelajaran Matematika dan Pendidikan Jasmani Olahraga dan Kesehatan (PJOK) sebagai mata pelajaran yang berdiri sendiri untuk kelas IV,V, dan VI. Untuk mempermudah menerapkan semua mata pelajaran tersebut, dapat dilakukan dengan menggunakan tema untuk mengaitkan beberapa mata pelajaran. Pada kurikulum 2013, tema sudah disiapkan oleh pemerintah dan sudah dikembangkan menjadi subtema dan satuan pembelajaran. Kurikulum 2013 tidak mengenal mata pelajaran namun telah diubah menjadi muatan. Dalam menerapkan pembelajaran dibutuhkan guru yang pandai dan inovatif dalam menggunakan strategi yang tepat dalam pembelajaran. Salah satu strategi yang dapat diterapkan dengan penggunaan media dalam pembelajaran. Berikut pentingnya penggunaan media menurut (Syamsu, 2017: 26) yaitu: (1) digunakan guru dalam proses berinteraksi dengan siswa, (2) untuk menyampaikan pesan dan merangsang pikiran; (3) mendorong siswa terlibat langsung dalam pembelajaran; (4) siswa akan ikut berpartisipasi secara aktif dalam pembelajaran.

Menurut (Wisudawati, 2014) tujuan dari kurikulum 2013 adalah mengembangkan potensi-potensi yang dimiliki oleh peserta didik baik itu kemampuan sikap religius, sikap sosial, intelektual, kemampuan berkomunikasi, sikap peduli, dan partisipasi aktif peserta didik dalam menciptakan kehidupan berbangsa dan bermasyarakat yang baik. Dalam kurikulum 2013 guru dituntut memiliki kreativitas dan pola berpikir tingkat tinggi (Higher Order Thinking) pada pelaksanaan proses pembelajaran IPA di kelas. Proses pembelajaran IPA harus mempunyai makna yang diharapkan mampu meningkatkan kualitas pendidikan di Indonesia. Berdasarkan fakta-fakta yang ada di lapangan, bahwa proses pembelajaran IPA masih menitikberatkan pada hasil (result oriented), yaitu pencapaian nilai Ujian Nasional (UN). Dalam proses pembelajaran IPA belum sepenuhnya menyinggung pada ranah kebermaknaan dari konsep-konsep yang diperoleh dari bangku sekolah/kuliah. Mastery learning (belajar tuntas) dan meaningful learning (belajar bermakna) di dalam suatu proses pembelajaran IPA akan mampu meningkatkan motivasi belajar peserta didik. Karena seorang peserta didik belajar merupakan suatu ke wajiban bukan merupakan suatu kebutuhan. Maka diperlukan suatu proses pembelajaran IPA khusus yang mampu diaplikasikan oleh peserta didik dalam kehidupan nyata. Dengan demikian, proses pembelajaraan IPA mengutamakan penelitian dan pemecahan masalah. Hal ini terjadi ketika belajar IPA mampu meningkatkan proses berpikir peserta didik untuk memahami fenomena-fenomena alam. Adapun faktor-faktor yang mempengaruhi hasil nilai belajar IPA yang dicapai oleh peserta didik di Indonesia masih tergolong rendah, karena dipengaruhi oleh banyak faktor, yaitu: karakteristik peserta didik dan keluarga, kemampuan membaca, motivasi belajar, minat dan konsep diri, strategi belajar dan lingkungan belajar peserta didik.

Dalam proses pembelajaran yang terjadi selama ini, guru masih menerapkan pendekatan klasikal dan proses pembelajaran yang masih konvensional. Dimana suasana kelas cenderung teachercentered (cara belajar yang masih berpusat pada guru) dan metode yang digunakan adalah metode ceramah yang masih menjadi pilihan utama dalam pembelajaran. sehingga siswa menjadi pasif dan bosan seperti yang terjadi di SD Negeri Bringin 01, maka dapat didentifikasi yang perlu mendapatkan perhatiam antara lain: 1) Kurangnya kemampuan dan keterampilan yang dimiliki guru dalam memilih dan menggunakan model pembelajaran sehingga mengakibatkan siswa susah untuk menerima pembelajaran IPA dengan maksimal. 2) Pembelajaran IPA yang dilakukan oleh guru masih sangat kurang untuk mengembangkan budaya belajar siswa, sehingga siswa tidak memiliki motivasi belajar yang tinggi dan hasil belajar yang dicapai rendah. 3) Pembelajaran IPA yang diajarkan oleh guru dengan menggunakan model pembelajaran yang konvensional membuat siswa tidak aktif, dan bosan membuat siswa kurang berminat mengikuti pembelajatran. Dari berbagai masalah yang terjadi menyebabkan nilai hasil belajar siswa rendah. Ketuntasan hasil pembelajaran muatan IPA kelas 4 SD Negeri Bringin 01, dapat lihat dari 23 siswa terdapat 13 siswa yang belum tuntas/belum memenuhi KKM dengan presentase $57 \%$, dan siswa yang memenuhi KKM sebanyak 10 siswa dengan presentase $43 \%$. Berdasarkan dari data hasil belajar siswa tersebut dapat dikatakan 
hasil belajar siswa yang kurang baik karena masih banyak siswa yang belum memenuhi KKM (65).

Melihat kondisi yang terjadi, upaya untuk memecahkan masalah dengan merubah model pembelajaran yang sudah dipakai dengan model pembelajaran Problem Based Learning (PBL) dirasa ampuh dalam meningkatkan hasil belajar. Hal ini didukung oleh penelitian yang dilakukan Anggun Winata (2017: 21) di dalam penelitiannya yang berjudul "Penerapan Model PBL (Problem Based Learning) Untuk Meningkatkan Aktivitas dan Hasil Belajar Siswa Pada Mata Pelajaran IPA Materi Energi Bunyi Kelas IV Semester II Di SDN I Sedayulawas Brondong Lamongan Tahun Pelajaran 2015/2016" mengatakan bahwa keampuhan model Problem Based Learning (PBL) mampu meningkatkan aktivitas dan hasil belajar siswa. Hal ini diperkuat dengan hasil penelitian milik Ainur Indra Prasetya dan Citra Fitri Kholidya ( 2017: 1) dengan judul penelitian "Penerapan Model Problem Based Learning ( $P B L$ ) Terhadap Hasil Belajar Siswa Kelas V SDN Jabaran Sidoarjo Mata Pelajaran IPA Materi Pokok Bumi dan Alam Semesta”, menyatakan bahwa penerapan model pembelajaran Problem Based Learning ( $P B L$ ) dapat meningkatkan hasil belajar siswa.

Berdasarkan hasil penelitian yang telah ada maka terbukti bahwa model pembelajaran Problem Based Learning ( $P B L$ ) dianggap mempunyai potensi dalam meningkatkan hasil belajar siswa. Dengan menggunakan model pembelajaran Problem Based Learning (PBL) siswa diharapkan akan lebih tertarik pada pembelajaran IPA sehingga akan meningkatkan keterampilan, prestasi dan hasil belajar yang diinginkan. Dalam hal ini guru tidak hanya sekedar melaksanakan apa yang ada dalam kurikulum, melainkan harus dapat menginterprestasi dan mengembangkan kurikulum menjadi bentuk pembelajaran yang menarik. Pembelajaran dapat menarik apabila guru memiliki kreativitas dengan menerapkan metode yang dapat merangsang pikiran siswa dengan terlibatnya siswa dalam aktifitas belajar. Ketepatan penggunaan model dalam sebuah pembelajaran akan memberi suasana yang menyenangkan dalam proses belajar, sehingga siswa akan belajar dengan tekun seolah-olah proses belajar siswa dilakukan tanpa adanya keterpaksaan, tetapi justru belajar dengan rasa keharmonisan.

Berdasarkan studi lapangan dan hasil penelitian yang terdahulu maka model pembelajaran Problem Based Learning (PBL) di anggap ampuh untuk memperbaiki permasalahan yang terjadi yaitu meningkatkan hasil belajar siswa muatan IPA pada kelas 4 SDN Bringin 01. Oleh karena itu penulis tertarik untuk melakukan penelitian tindakan kelas dengan judul "Peningkatan Hasil Belajar Muatan IPA Melalui Model Pembelajaran Problem Based Learning (PBL) Berbantuan Media Audio Visual dan Gambar Pada Siswa Kelas 4 SD Negeri Bringin 01 Kabupaten Semarang
Tahun Pelajaran 2017/2018”. Agar hasil belajar siswa dapat mencapai KKM.

\section{B. METODE PENELITIAN}

Penelitian yang dilakukan oleh peneliti menggunakan model pembelajaran Problem Based Learning (PBL), di dalam pembelajaran Problem Based Learning (PBL) terdapat tahap-tahap pembelajaran yang sudah terstruktur secara runtut yang harus dilakukan oleh guru dalam proses pembelajaran di kelas. Adapun tahap-tahap pembelajaran model Problem Based Learning (PBL) ada 5 fase yang harus dilakukan oleh guru menurut Arends (2008: 57) yaitu a) Mengorientasikan siswa pada situasi masalah, b) Mengorganisasikan siswa untuk belajar atau penyelidikan, c) Memberikan bimbingan penyelidikan individual atau kelompok, d) Mengembangkan dan menyajikan hasil karya, e) Menganalisis dan mengevaluasi proses penyelesaian masalah yang ada.

Jenis penelitian yang akan dilaksanakan adalah Penelitian Tindakan Kelas (Classroom Action Research). Penelitian tindakan kelas yaitu suatu tindakan penelitian yang dilakukan oleh guru untuk dipergunakan dalam memecahkan sebuah masalah yang ada di dalam kelas selama proses pembelajaran berlangsung dan untuk memperbaiki pengajaran guru secara praktis (Sukidin dkk,2010: 82). Peneliti akan melakukan tindakan penelitian dengan menggunakan model pembelajaran Problem Based Learning (PBL) yang akan dilaksanakan dalam 2 siklus, setiap siklus terdiri dari tiga kali pertemuan . Adapun tujuan dari penelitian ini adalah untuk meningkatkan hasil belajar pesertadidik pada muatan IPA tema 7 Indahnya Keragaman di Negeriku pada kelas 4 A SD Negeri Bringin 01 melalui tindakan penerapan model Problem Based learing (PBL) di dalam pembelajaran.

Penelitian tindakan kelas termasuk penelitian yang bersifat reflektif dengan melaksanakan tindakantindakan tertentu untuk memperbaiki atau meningkatkan praktik pembelajaran guru di kelas dengan lebih profesional (Sunardi dan Tri Widiarto,2012: 13). Kegiatan penelitian dimulai dari permasalahan yang riil yang dihadapi oleh guru di kelas dalam proses belajar mengajar, kemudian direfleksikan pemecahan masalah tersebut. Setelah itu masalah tersebut ditindak lanjuti dengan tindakan-tindakan terencana dan terstruktur oleh peneliti. Pelaksanakan penelitian tindakan kelas dilakukan dengan beberapa tahap yaitu perencanaan, pelaksanaan, obsevasi/evaluasi, dan refleksi.

Dalam Penelitian ini penulis menggunakan model PTK yang dikemukakan oleh Stephen Kemmis dan Robin Mc. Taggart (Arikunto, Suhardjono, supardi: 2007), yang akan dilaksanakan minimal 2 siklus, dengan langkah-langkah dalam masing-masing siklus terdiri dari 3 langkah yaitu planning (perencanaan), acting dan observation (tindakan dan observasi), dan reflecting (refleksi). Keseluruhan unraian tersebut diartikan 
sebagai satu siklus. Dalam Penelitian Tindakan Kelas (PTK), terdapat beberapa siklus. Banyaknya siklus yang dilaksanakan dalam penelitian tindakan kelas ini tidak ditentukan. Siklus akan selesai jika tujuannya sudah tercapai sesuai dengan rencana yang telah dibuat. Pada tahapan prosedur penelitian ini ditunjukkan melalui gambar berikut ini.

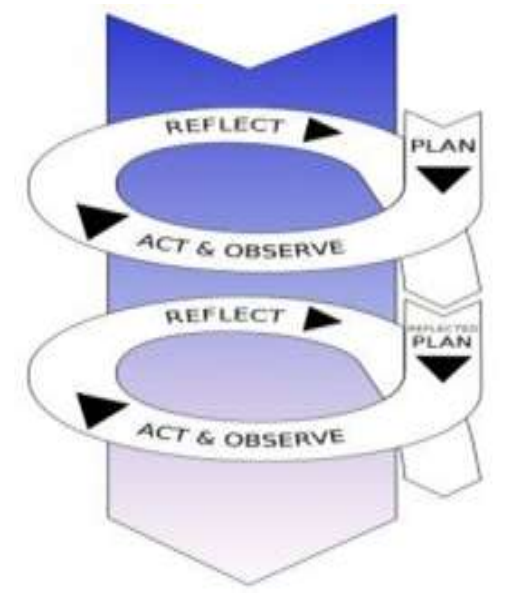

Gambar 1. Model Penelitian Tindakan Kelas Dengan Model Spiral dari Stephen Kemmis dan Robin Mc. Taggart

Model penelitian yang digunakan dalam penelitian ini adalah PTK. Model ini dilaksanakan sebanyak dua siklus, dengan setiap siklusnya terdiri dari tiga kali pertemuan.

Hasil data penelitian ini diperoleh dari hasil observasi dan hasil belajar siswa yaitu (a) hasil data pada lembar observasi aktivitas guru dalam menggunakan model pembelajaran Problem Based Learning (PBL) selama proses pembelajaran berlangsung dari siklus I dan siklus II. (b) hasil data dari lembar observasi aktivitas siswa dalam menerapkan model pembelajaran Problem Based Learning (PBL) selama mengikuti proses pembelajaran berlangsung dari siklus I dan siklus II. (c) data hasil belajar siswa yang didapat dari tes evaluasi yang di berikan guru pada setiap akhir pembelajaran siklus I dan siklus II selama kegiatan proses pembelajaran berlangsung.

Kriteria keberhsilan yang ditetapkan oleh peneliti pada penelitian ini adalah penggunaan model pembelajaran Problem Based Learning (PBL) dalam pembelajaran muatan IPA dikatakan berhasil bila mana indikator keberhasilan dalam penelitian tindakan kelas ini menunjukan presentase hasil belajar yaitu, ketuntasan individu siswa mencapai ketuntasan KKM $\geq$ 65 dan ketentuan klasikal jika $75 \%$ dari siswa yang mengikuti proses belajar mengajar telah mencapai KKM sebesar 65 .

\section{HASIL DAN PEMBAHASAN}

\section{Hasil Penelitian}

\section{a. Aktivitas Guru}

Hasil dari penelitian observasi yang dilakukan dengan menggunakan angket lembar observasi aktivitas guru selama proses pembelajaran berlangsung dengan menerapkan model pembelajaran Problem Based Learning (PBL) dapat diperoleh hasil presentase aktivas guru pada siklus I dan siklus II yang tiap-tiap siklus terdiri dari 2 kali tatap muka dan 1 kali tes akhir evaluasi dari 3 kali pertemuan. Aktivitas guru pada siklus I pertemuan 1 menunjukkan bahwa 10\% dari tahap-tahap lembar observasi tidak dilakukan, dan 90\% dari tahap-tahap lembar observasi sudah dilakukan dengan baik, sedangkan pada siklus I pertemuan 2 menunjukkan bahwa 100\% dari tahap-tahap lembar observasi sudah dilakukan dengan baik. Hasil aktivitas guru pada siklus I sudah baik, tetapi masih perlu diperbaiki lagi pada siklus II supaya sesuai dengan rencana dan susunan pembelajaran yang sudah dibuat sesuai dengan langkah-langkah model pembelajaran Problem Based Learning. Aktivitas guru pada siklus II pertemuan 1 dan pertemuan 2 menunjukkan bahwa aktivitas yang dilakukan guru memperoleh angka presentase 100\% dari tahap-tahap lembar observasi aktivitas guru sudah dilakukan dengan baik. Aktivitas guru dari siklus I dan siklus II mengalami peningkatan dan masuk dalam kategori sangat baik.

\section{b. Aktivitas Siswa}

Berdasarkan hasil observasi aktivitas siswa pada proses pembelajaran yang sedang berlangsung di kelas dengan menggunakan lembar observasi aktivitas siswa dengan menggunakan model pembelajaran Problem Based Learning (PBL). bahwa aktivitas siswa pada siklus I dan siklus II yang tiap-tiap siklus terdiri dari 2 kali tatap muka dan 1 kali tes akhir evaluasi dari 3 kali pertemuan. Aktivitas siswa pada siklus I pertemuan 1 menunjukkan bahwa $5 \%$ dari tahap-tahap lembar observasi tidak dilakukan, dan 95\% dari tahap-tahap lembar observasi sudah dilakukan dengan baik, sedangkan pada siklus I pertemuan 2 menunjukkan bahwa 100\% dari tahap-tahap lembar observasi sudah dilakukan dengan baik. Hasil aktivitas siswa pada siklus I sudah baik, tetapi masih perlu diperbaiki lagi pada siklus II supaya pada kegiatan proses pembelajaran berlangsung sesuai dengan rencana dan susunan pembelajaran yang sudah dibuat dan sesuai dengan langkah-langkah model pembelajaran Problem Based Learning. Kemudian hasil aktivitas siswa pada siklus II pertemuan 1 dan pertemuan 2 menunjukkan 
bahwa aktivitas yang dilakukan siswa memperoleh angka presentase $100 \%$ dari tahap-tahap lembar observasi sudah dilakukan dengan baik. Aktivitas siswa dari siklus I dan siklus II mengalami peningkatan dan masuk dalam kategori sangat baik.

\section{c. Peningkatan hasil Belajar Siswa}

Hasil dari tindakan penelitian dengan membandingkan data pada pra siklus, siklus I dan siklus II, dapat diketahui bahwa terjadi peningkatan ketuntasan hasil belajar siswa pada muatan IPA di kelas 4 A SD Negeri Bringin 01 Semester 2 Tahun Pelajaran 2017/2018. Perbandingan hasil belajar siswa pada pra siklus, siklus I dan siklus II dapat di sajikan pada tabel dan gambar berikut ini.

TABEL 1

PERBANDINGAN HASIL BELAJAR MUATAN IPA

SISWA KELAS 4 A SD NEGERI BRINGIN 01 PADA PRA SIKLUS, SIKLUS I, DAN SIKLUS II

\begin{tabular}{|c|c|c|c|c|c|c|c|}
\hline \multirow[t]{2}{*}{ No } & \multirow{2}{*}{$\begin{array}{c}\text { Ketunt } \\
\text { asan }\end{array}$} & \multicolumn{2}{|c|}{$\begin{array}{c}\text { Pra } \\
\text { Siklus }\end{array}$} & \multicolumn{2}{|c|}{ Siklus I } & \multicolumn{2}{|c|}{ Siklus II } \\
\hline & & $\mathbf{f}$ & $\%$ & $\mathbf{f}$ & $\%$ & $\mathbf{f}$ & $\%$ \\
\hline 1. & Tuntas & 10 & $43 \%$ & 16 & $70 \%$ & 22 & $96 \%$ \\
\hline 2. & $\begin{array}{l}\text { Tidak } \\
\text { Tuntas }\end{array}$ & 13 & $57 \%$ & 7 & $30 \%$ & 1 & $4 \%$ \\
\hline \multicolumn{2}{|c|}{ Jumlah } & 23 & $100 \%$ & 23 & $100 \%$ & 23 & $100 \%$ \\
\hline \multicolumn{2}{|c|}{ Rata-rata } & \multicolumn{2}{|c|}{48,6} & \multicolumn{2}{|l|}{65} & \multicolumn{2}{|c|}{77,61} \\
\hline \multicolumn{2}{|c|}{ Nilai Tertinggi } & \multicolumn{2}{|c|}{75} & \multicolumn{2}{|l|}{75} & \multicolumn{2}{|c|}{95} \\
\hline \multicolumn{2}{|c|}{ Nilai Terendah } & \multicolumn{2}{|c|}{40} & \multicolumn{2}{|l|}{45} & \multicolumn{2}{|l|}{55} \\
\hline
\end{tabular}

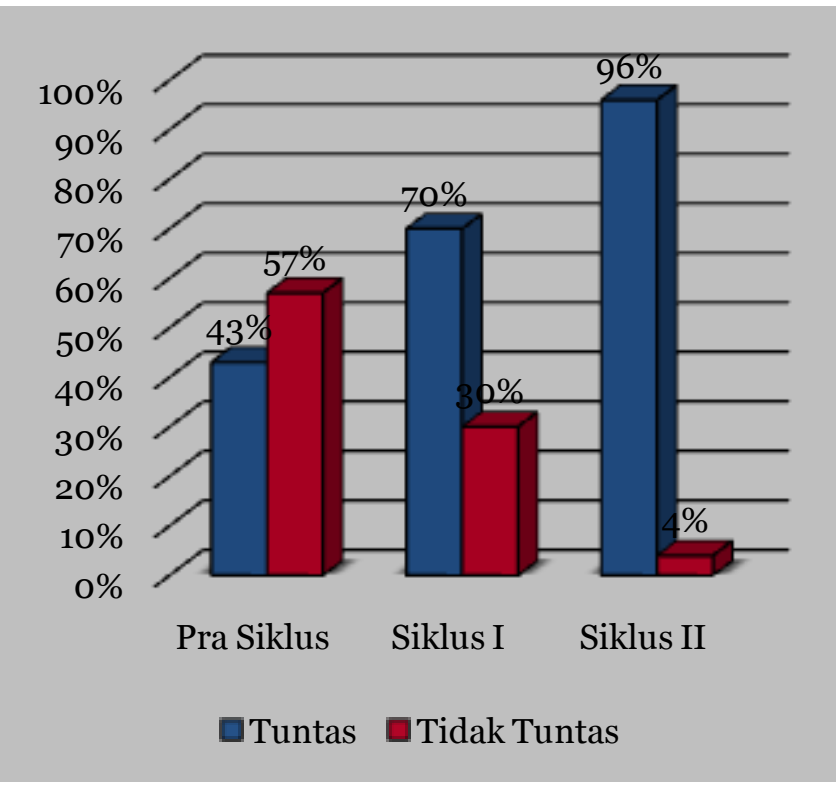

Gambar 2. Grafik Perbandingan Ketuntasan Hasil Belajar Muatan IPA Siswa Kelas 4 A SD Negeri Bringin o1 Pra Siklus, Siklus I, dan Siklus II

Berdasarkan hasil penelitian tindakan kelas, data yang disajikan pada tabel dan gambar di atas dapat dilihat bahwa hasil belajar siswa pada pembelajaran muatan IPA di kelas 4 A SD Negeri Bringin 01 yang memiliki Kriteria Ketuntasan
Minimal (KKM) 65 yang sudah ditetapkan oleh sekolah. Dengan menerapkan model pembelajaran Problem Based Learning (PBL) berbantuan media audio visual dan gambar dari pra siklus sampai siklus II menunjukkan peningkatan yang sangat baik. Hal ini dapat ditunjukkan pada pra siklus siswa yang mencapai nilai KKM berjumlah 10 siswa dengan presentase $43 \%$, sedangkan siswa yang tidak atau belum mencapai nilai KKM sebanyak 13 siswa dengan presentase $57 \%$. Dengan nilai rata-rata adalah 48,6. Dengan perolehan nilai tertinggi pada kondisi awal ini adalah 75 dan perolehan nilai terendah adalah 40 . Sedangkan pada siklus I hasil belajar siswa mengalami peningkatan, yaitu siswa yang mencapai nilai KKM adalah 16 dengan presentase $70 \%$ dan siswa yang tidak mencapai KKM sebanyak 7 siswa dengan presentase $30 \%$. Nilai rata-rata pada siklus I ini adalah 65 , dengan perolehan nilai tertinggi adalah 75 dan perolehan nilai siswa terendah adalah 45 . Selnjutnya pada tindakan siklus II ini diperoleh data siswa yang mencapai nilai KKM berjumlah 22 siswa dengan presentase $96 \%$ dari 23 siswa dan siswa yang belum tuntas atau belum mencapai nilai KKM adalah 1 siswa dengan presentase $4 \%$ dari jumlah keseluruhan 23 siswa. Dengan nilai rata-rata yang dipeoleh siswa pada siklus II adalah 77,61, dengan nilai tertinggi yang diperoleh siswa adalah 95 dan nilai terendah yang diperoleh siswa pada siklus II ini adalah 55. Dari hasil data yang diperoleh peneliti pada kondisi awal, siklus I dan siklus II menunjukkan peningkatan hasil belajar siswa.

Berdasarkan hasil data penelitian yang menunjukkan kenaikan hasil belajar siswa, hal ini membuktikan bahwa penerapan model pembelajaran Problem Based Learning (PBL) berbantuan media audio visual dan gambar pada muatan IPA siswa kelas 4 A SD Negeri Bringin 01 Semester 2 Tahun Pelajaran 2017/2018 dapat meningkatkan hasil belajar siswa.

\section{Pembahasan}

Berdasarkan hasil analisis data di atas, dapat dilihat bahwa hasil belajar siswa SD Negeri Bringin o1 mengalami peningkatan yang signifikan setelah dilakukan kegiatan pembelajaran dengan menggunakan model pembelajaran Problem Based Learning (PBL). Meningkatnya hasil belajar siswa ini di pengaruhi oleh pembelajaran dengan menggunakan model Problem Based Learning ini menggunakan sebuah permasalahan sebagai fokus utama dalam pembelajaran, siswa dapat melakukan penyelidikan untuk memecahkan masalah yang disampaikan oleh guru, dengan mengikuti langkahlangkah Problem Based Learning (PBL) yaitu (a) mengorientasikan siswa pada sebuah masalah bisa menggunakan video, gambar dan animasi, (b) mengorganisasikan siswa untuk belajar atau penyelidikan, (c) membimbing siswa untuk 
penyelidikan individual atau kelompok, (d) mengembangkan dan menyajikan hasil karya yang telah dibuat, (e) menganalisis dan mengevaluasi hasil dari pemecahan masalah.

Berdasarkan hasil belajar siswa pada kondisi awal atau kondisi pra sikus pada siswa kelas 4 A SD Negeri Bringin 01 Kecamatan Bringin Kabupaten Semarang dengan subjek penelitian sebanyak 23 siswa yang terdiri dari 11 siswa laki-laki dan 12 siswa perempuan. Terdapat sebanyak 10 siswa dengan presentase $43 \%$ yang sudah memenuhi kriteria KKM $\geq 65$, sedangkan sebanyak 13 siswa dengan presentase $57 \%$ masih belum memenuhi kriteria atau dibawah KKM < 65 yang sudah ditetapkan oleh sekolahan dalam proses Kegiatan Belajar Mengajar (KBM) pada muatan IPA. Permasalahan ini dikarenakan dalam proses pembelajaran didalam kelas guru masih menggunakan metode yang masih konvensional yaitu dengan ceramah dan dilanjutkan dengan pemberian tugas kepada siswa. Hal ini tidak sesuai dengan karakteristik pembelajaran IPA yang menyenangkan. Dari kondisi permasalahan yang terjadi maka diperlukan suatu model pembelajaran yang sesuai dengan karakteristik pembelajaran IPA untuk menimbulkan rasa ingin tau siswa salah satunya dengan model pembelajaran Problem Based Learning (PBL). Peneliti ingin mecoba menerapkan model pembelajaran Problem Based Learning (PBL) pada proses kegiatan pembelajaran dan untuk menarik minat, perhatian siswa. Penelitian tindakan kelas ini dilakukan dalam dua siklus masing-masing siklus terdiri dari 3 kali pertemuan, dan penelitian ini didasari dengan permasalahan yang ada pada kondisi awal. Penelitian tindakan ini dibantu oleh guru kelas dan rekan mahasiswa sebagai observer sehingga bisa berjalan dengan baik.

Setelah peneliti melakukan tindakan yaitu dengan menerapkan model pembelajaran Problem Based Learning (PBL) pada proses pembelajaran siklus I, dapat dilihat meningkatnya hasil belajar siswa dari kondisi awal / pra siklus ke siklus I adalah sebesar 16 siswa dengan presentase 70\% sudah mencapai $\mathrm{KKM} \geq 65$, sedangkan 7 siswa dengan presentase 30\% masih di bawah KKM $<65$ dan nilai rata-rata muatan IPA yang di peroleh sebesar 65 . Hasil observasi ini menunjukan bahwa penelitian tindakan yang dilakukan pada siklus I dalam proses pembelajaran sudah berjalan dengan baik tetapi dikatakan belum berhasil dikarenakan masih terdapat kekurangan yang terjadi yaitu siswa masih mengalami kebingungan dalam menyelesaikan tugas yang diberikan, dalam memberikan orientasi kepada siswa terhadap sebuah masalah guru belum memberikan permasalahan secara kontektual, kemudian dalam membimbing diskusi kelompok guru masih belum maksimal dalam memberikan bimbingan sehingga siswa kurang berpartisipasi dalam diskusi kelompok, dan dalam menyajikan hasil karya banyak siswa yang lebih asik sibuk sendiri dengan kelompoknya dan kurang memper hatikan temannya saat menyampaikan hasil karyanya di depan kelas. Setelah dilakukan evaluasi pada siklus I, maka peneliti merancang solusi dari permasalahan yang ada pada siklus I yaitu diantaranya guru perlu lebih memahami tahap-tahap pembelajaran dengan menggunakan model pembelajaran Problem Based Learning (PBL) dapat terlaksana dengan baik, dalam proses pembelajaran guru harus memberikan sebuah permasalahan yang kontekstual dalam kehidupan sehari-hari kepada siswa, dalam diskusi kelompok guru harus lebih sering berkeliling untuk memberikan bimbingan kepada setiap kelompok secara bergantian, dalam menyampaikan hasil karya supaya siswa berpartisipasi aktif dalam menyajikan hasil karya guru harus memberikan sebuah apresiasi kepada setiap kelompok setelah mempresentasikan hasil pekerjaannya di depan kelas dan guru perlu menanamkam sikap menghargai orang lain kepada siswa supaya siswa selalu memperhatikan jika ada orang yang sedang berbicara didepannya.

Hasil penelitian observasi yang dilakukan pada siklus II menunjukkan bahwa adanya peningkatan yang baik terhadap guru maupun siswa, hal ini membuktikan bahwa pembelajaran yang dilakukan oleh guru, telah dapat melaksanakan model pembelajaran Problem Based Learning (PBL) dengan baik sesuai dengan langkah-langkahnya dan ketuntasan belajar siswa mengalami peningkatan.

Penelitian pada tindakan siklus II menunjukkan bahwa adanya peningkatan hasil belajar yang diperoleh siswa yaitu, sebesar 22 siswa dengan presentase 96\% siswa sudah mencapai KKM $\geq 65$, sedangkan 1 siswa dengan presentase $4 \%$ masih di bawah $\mathrm{KKM}<65$ dan nilai rata-rata muatan IPA yang di peroleh sebesar 77,61. Hal ini membuktikan bahwa tindakan penelitian siklus II untuk upaya meningkatkan hasil belajar siswa dengan menerapkan model pembelajaran Problem Based Learning (PBL) dikatakan sudah berhasil karena telah melampaui indikator keberhasilan yang sudah ditentukan oleh peneliti yaitu 70\% dari jumlah siswa yang mendapat nilai mencapai KKM (65). Hal ini dapat dilihat sebanyak 96\% dari jumlah siswa yang mengikuti proses kegiatan belajar mengajar (KBM) telah mencapai KKM (65). Berdasarkan hasil nilai yang diperoleh siswa pada siklus I dan siklus II dapat disimpulkan bahwa model pembelajaran Problem Based Learning (PBL) berbantuan media audio visual dan gambar yaitu salah satu model yang memiliki suatu keunggulan untuk meningkatkan hasil belajar siswa pada muatan Ilmu Pengetahuan Alam (IPA) kelas 4 A SD Negeri Bringin 01 Kecamatan Bringin Kabupaten Semarang Tahun Pelajaran 2017/2018. 
Hasil penelitian ini juga diperkuat dengan penelitian-penelitian lain dengan model Problem Based Learning (PBL) yang dilakukan oleh, Dede Dewantara (2016: 41) dengan judul penelitian "Penerapan Model Pembelajaran Problem Based Learning untuk Meningkatkan Aktivitas dan Hasil Belajar Siswa Pada Pelajaran IPA (Studi Pada Siswa Kelas V SDN Pengambangan 6 Banjarmasin)” yang menyatakan bahwa model pembelajaran Problem Based Learning (PBL) atau berbasis masalah terbukti dapat meningkatkan hasil belajar siswa hingga mencapai indikator keberhasilan. Selanjutnya penelitian yang dilakukan oleh, Yenni Fitria Surya (2017: 38) dengan judul penelitian "Penerapan Model Pembelajaran Problem Based Learning untuk Meningkatkan Hasil Belajar Matematika Siswa Kelas IV SDN 016 Langgini Kabupaten Kampar" hasil penelitian yang dilakukan menunjukkan bahwa pemeblajaran dengan menggunkan model Problem Based Learning (PBL) dapat meningkatkan hasil belajar siswa pada pembelajaran Matematika kelas IV SDN 016 Langgini Tahun Ajaran 2016/2017. Hal ini terbukti dengan adanya peningkatan dari kondisi awal ke siklus I dan ke siklus II, sebelum dilakukan tindakan hasil belajar siswa yang mencapai KKM sebesar 13 siswa dengan nilai rata-rata klasikal sebesar $48 \%$. Pada tindakan siklus I yang mencapai KKM sebesar 19 siswa dengan nilai rata-rata klasikal sebesar 70\%. Kemudian pada tindakan siklus II yang mencapai KKM sebesar 25 siswa dengan nilai ratarata klasikal sebesar 92\%. Jadi, dengan menerapkan model pembelajaran Problem Based Learning (PBL) dapat meningkatakan hasil belajar siswa pada pembelajaran Matematika. Kemudian penelitian yang dilakukan oleh, Wiwik Kusumawati (2015: 1) dengan judul penelitian "Penerapan Model Problem Based Learning Pada Mata Pelajaran IPS untuk Meningkatkan Hasil Belajar Siswa Kelas VI SDN Sembero 01 Kecamatan Semboro Kabupaten Jember Tahun Ajaran 2014/2015". Hasil penelitian menunjukkan bahwa adanya peningkatan dari kondisi awal ke siklus I dan ke siklus II, sebelum dilakukan tindakan pada kondisi awal hasil belajar siswa sebesar 31,3\% dengan nilai rata-rata kelas 52,6. Pada tindakan siklus I nilai rata-rata kelas meningkat sebesar 74,6 dengan presentae ketuntasan siswa yang mencapai KKM sebesar 62,5\%. Kemudian pada tindakan siklus II mengalami peningkatan yang signifikan yaitu nilai rata-rata kelas sebesar 82,8 dengan presentase ketuntasan siswa yang mencapai KKM sebesar 99,6\% dan hasil belajar siswa mencapai indikator ketuntasan minimal secara klasikla yang sudah ditetapkan. Jadi, dengan menerapkan model pembelajaran Problem Based Learning (PBL) dapat meningkatkan hasil belajar siswa kelas VI SDN Sembero 01 pada mata pelajaran IPS. Penelitian yang dilakukan oleh Yudha Widhiatma dan Wasitohadi
(2017: 447) dengan judul penelitian "Penerapan Model Problem Based Learning untuk Meningkatkan Hasil Belajar IPA Siswa kelas 4 SDN Kalinanas 01" hasil penelitian yang dilakukan oleh peneliti menunjukkan bahwa dengan penerapan model pembelajaran Problem Based Learning (PBL) dapat meningkatkan hasil belajar siswa pada pembelajaran IPA.

Hasil dari tindakan penelitian yang sudah dilakukan ini telah menjawab indikator keberhasilan yang ditentukan oleh peneliti adalah hasil belajar siswa dapat dikatakan berhasil apabila $75 \%$ dari 23 siswa telah berhasil mencapai Kriteria Ketuntasan Minimal (KKM). KKM yang ditentukan oleh SD Negeri Bringin o1 untuk muatan IPA adalah 65 . Didalam penelitian yang sudah dilakukan dapat di lihat bahwa ketuntasan siswa pada siklus II telah mencapai $96 \%$ yang artinya ketuntasan pada siklus II telah menjawab indikator keberhasilan yang sudah ditetapkan.

Penerapan model pembelajaran Problem Based Learning (PBL) berbantuan media audio visual dan gambar terbukti dapat meningkatkan hasil belajar siswa pada pembelajaran muatan IPA siswa kelas 4A SD Negeri Bringin 01 Kecamatan Bringin Kabupaten Semarang Tahun Pelajaran 2017/2018. Efek yang terjadi setelah menerapkan penelitian tindakan kelas ini yaitu guru dapat menggunakan model pembelajaran yang aktif, inovatif, kreatif, efektif, dan menyenagkan (PAIKEM) untuk merubah mutu dalam proses pembelajaran. Pengetahuan dan keterampilan yang dimiliki guru semakin berkembang dengan menerapkan model-model pembelajaran yang aktif, inovatif, kreatif, efektif dan menyenangkan bagi siswa. Model pembelajaran ini juga bisa digunakan sebagai upaya perbaikan dalam proses pembelajaran untuk meningkatkan profesionalisme kerja guru.

\section{SIMPULAN DAN SARAN}

\section{Simpulan}

Berdasarkan hasil tindakan penelitian dan pembahasan pada BAB IV, dapat disimpulkan bahwa dari proses pembelajaran dengan menerapkan model pembelajaran Problem Based Learning (PBL) berbantuan media audio visual dan gambar dapat meningkatkan hasil belajar siswa pada pembelajaran muatan IPA Kelas 4 A SD Negeri Bringin 01 Kecamatan Bringin Kabupaten Semarang Semester 2 Tahun Pelajaran 2017/2018. Hal ini telah dibuktikan dengan peningkatan hasil belajar siswa pada muatan IPA dari setiap tindakan siklus.

Setelah dilakukan penerapan model pembelajaran Problem Based Learning (PBL) pada siswa kelas 4 A SD Negeri bringin o1 telah mengalami peningkatan hasil belajar pada muatan IPA. Dimana pada persentase ketuntasan secara klasikal telah 
meningkat dari kondisi awal pra siklus sebanyak 10 siswa dengan presentase $43 \%$ telah mencapai nilai KKM dan 13 siswa dengan presentase $57 \%$ belum mencapai nilai $\mathrm{KKM}$, dengan nilai rata-rata kelas yang diperoleh siswa sebesar 48,6. Setelah dilakukan tindakan perbaikan pada proses kegiatan pembelajaran pada siklus I ketuntasan hasil belajar siswa mengalami peningkatan yaitu sebesar 16 siswa dengan presentase $70 \%$ telah mencapai nilai KKM, dan 7 siswa dengan presentase $30 \%$ belum mencapai nilai KKM, dengan nilai rata-rata kelas yang diperoleh siswa pada siklus I sebesar 65. Sedangkan tindakan kegiatan pembelajaran yang dilakukan pada siklus II hasil belajar siswa pada muatan IPA kembali mengalami peningkatan dengan perolehan hasil sebesar 22 siswa dengan presentase 96\% siswa telah mencapai nilai KKM, dan 1 siswa dengan presentase $4 \%$ belum mencapai nilai $\mathrm{KKM}$, dengan nilai ratarata kelas yang diperoleh siswa pada siklus II sbesar 77,61. Dengan menggunakan model pembelajaran Problem Based Learning (PBL) dapat meningkatkan hasil belajar siswa dan dapat meningkatkan kemampuan guru dalam mengelola kegiatan proses pembelajaran dengan baik, sehingga guru lebih kreatif dan inovatif dalam proses pembelajaran dan siswa menjadi lebih aktif dan termotifasi dalam mengikuti proses kegiatan pembelajaran yang berlangsung.

\section{Saran}

Berdasarkan hasil penelitian yang dilakukan pada siswa kelas 4 A SD Negeri Bringin 01 Kecamatan Bringin Kabupaten Semarang semester 2 tahun pelajaran 2017/2018, peneliti memiliki beberapa saran sebagai berikut:

\section{a. Saran Teoritis}

Dari hasil tindakan penelitian yang dilakukan ini membuktikan bahwa penerapan model pembelajaran Problem Based Learning (PBL) ternyata dapat meningkatkan hasil belajar siswa pada muatan Ilmu Pengetahuan Alam (IPA) kelas 4 A SD Negeri Bringin 01 semester 2 tahun pelajaran 2017/2018. Dengan kata lain model pembelajaran Problem Based Learning (PBL) dapat diterapkan pada tema pembelajaran yang lain sehingga penerapan yang dilakukan pada kegiatan belajar mengajar dengan menggunakan model pembelajaran Problem Based Learning (PBL) semakin luas dan diharapkan mampu meningkatkan ketuntasan hasil belajar siswa pada tema pembelajaran yang lain.

\section{b. Saran Praktis \\ Bagi Guru}

1) Dengan menggunakan model pembelajaran Problem Based Learning (PBL) guru dapat meningkatkan hasil belajar siswa pada muatan IPA dan tema pembelajaran yang lainnya.
2) Guru dapat menggunakan model pembelajaran Problem Based Learning (PBL) sesuai dengan langkah-langkahnya dan penggunaan media juga harus disesuaikan dengan model pembelajaran yang digunakan.

3) Dengan menggunakan model-model pembelajaran yang kreatif, inovatif dan modern diharapkan guru harus lebih inovatif agar siswa lebih semangat dan termotivasi untuk mengikuti kegiatan belajar mengajar di sekolah.

\section{Bagi Siswa}

1) Siswa lebih aktif dan giat belajar di rumah maupun di sekolahan serta dapat bekerjasama dengan antar siswa secara baik di kelas maupun di luar kelas dalam kelompok sehingga hasil belajar siswa yang dicapai sesuai dengan yang diharapkan.

2) Dengan diterapkan model dan metode pembelajaran yang baru kepada siswa diharapkan dapat membantu kesulitankesulitan yang dialami siswa dalam proses kegiatan belajar mengajar.

3) Siswa dapat melakukan penyelidikan untuk mencari sebuah informasi dan mendapatkan sebuah jawaban dari penyelesaian masalah tersebut. Siswa dapat mengumpulkan sebuah data yang didapat dan menyajikan data itu menjadi sebuah hasil laporan dan mempresentasikan hasil laporannya.

\section{Bagi Sekolah}

1) Memberikan dukungan dalam memilih model pembelajaran untuk memperbaiki kegiatan didalam proses pembelajaran terkait dengan penerapan model pembelajaran Problem Based Learning (PBL) atau dengan model pembelajaran yang lainya dalam setiap penyampaian materi pembelajaran di sekolah.

2) Diharapkan sekolah bisa dapat menerapkan model dan metode pembelajaran yang modern agar peningkatan hasil belajar siswa menjadi lebih baik dan memfasilitasi guru dalam menerapkan model pembelajaran di kelas.

\section{Bagi Peneliti Lain}

Bagi peneliti selanjutnya dalam menggunakan model pembelajaran Problem Based Learning (PBL) agar lebih kreatif dan inovatif dalam menyediakan media atau bahan ajar dan rancangan pembelajaran yang baik supaya hasil belajar siswa mengalami peningkatan secara maksimal. 


\section{UCAPAN TERIMA KASIH}

Penulis mengucapkan terima kasih kepada Bapak Dr. Wasitohadi, M.Pd selaku dosen pembimbing 1 dan Ibu Theresia Sri Rahayu. S.Pd., M.Pd selaku dosen pembimbing 2 yang senantiasa memberikan bimbingan, nasehat, dan motivasi sehingga penelitian ini dapat selesai dengan baik. Tidak lupa juga ucapan terima kasih kepada semua pihak yang telah membantu dalam proses penelitian ini, terutama kepada Kepala Sekolah, Bapak dan Ibu guru SD Negeri Bringin 01 yang telah mengijinkan melakukan penelitian di SD tersebut dan terimakasih kepada orang tua yang selalu memberikan semangat dan doa, serta teman-teman yang telah mendukung dan memberikan semangat dalam proses penelitian ini.

\section{DAFTAR RUJUKAN}

[1] Arends, R. 2008. Belajar Untuk Mengajar. Yogyakarta: Pustaka Pelajar.

[2] Arikunto, Suharsinmi, Suhardjono, Supardi. 2007. Penelitian Tindakan Kelas. Jakarta: Bumi Aksara.

[3] Dewantara, D. 2016. Penerapan Model Pembelajaran Problem Based Learning untuk Meningkatkan Aktivitas dan Hasil Belajar Siswa Pada Pelajaran IPA ( Studi Pada Siswa Kelas V SDN Pengambangan 6 Banjarmasin). Jurnal Paradigma, Vol. 11, No. 2, h. 41-44, Juli 2016.

[4] Kusumawat, W. 2015. Penerapan Model Problem Based Learning Pada Mata Pelajaran IPS untuk Meningkatkan Hasil Belajar Siswa Kelas VI SDN Semboro 01 Kecamatan Semboro Kabupaten Jember Tahun Ajaran 2014/2015. Pancaran, Vol. 4, No. 4, h. 1-12, Nopember 2015.

[5] Permendikbud. 2016. Standar Penilaian Pendidikan. Jakarta: Menteri Pendidikan dan Kebudayaan Republik Indonesia.

[6] Permendikbud. 2016. Standar Proses Pendidikan Dasar dan Menengah. Jakarta: Menteri Pendidikan dan Kebudayaan Republik Indonesia.

[7] Permendikbud. 2016. Kompetensi Inti dan Kompetensi Dasar Pelajaran Pada Kurikulum 2013 Pada Pendidikan Dasar dan Pendidikan Menengah. Jakarta: Menteri Pendidikan dan Kebudayaan Republik Indonesia.

[8] Prasetya, A. I., \& Kholidya, C. F. 2017. Penerapan Model Problem Based Learning (PBL) Terhadap Hasil Belajar Siswa Kelas V SDN Jabaran Sidoarjo Mata Pelajaran IPA Materi Pokok Bumi dan Alam Semsta. E-Journal UNESA, Vol. 1, No. 3, 1.

[9] Sukidin, dkk. 2010. Manajemen Penelitian Tindakan Kelas. Surabaya: Insan Cendikia.

[10] Syamsu, F. D. (2017: 26). Pengembangan LKS Biologi Berbasis Kontekstual Dilengkapi dengan Mind Map pada Materi Archaebacteria dan Eubacteria untuk Siswa SMA. Bionatural, Vol. 4, No. 1, 26.

[11] Surya, Y.F. 2017. Penerapan Model Pembelajaran Problem Based Learning untuk Meningkatakan Hasil Belajar Matematika Siswa Kelas IV SDN 016 Langgini Kabupaten Kampar. Journal Cendekia: Jurnal Pendidikan Matematika, Vol. 1, No. 1, h. 38-53, Mei 2017.

[12] Widiarto, Tri, dan Sunardi. 2012. Penelitian Tindakan Kelas Untuk Ilmu Pengetahuan Sosial. Salatiga: Widya Sari Press Salatiga.
[13] Wisudawati, A. D. (2014). Metodologi Pembelajaran IPA. Jakarta: PT Bumi Aksara.

[14] Winata, A. 2017. Penerapan Model PBL (Problem Based Learning) untuk Meningkatkan Aktivitas dan Hasil Belajar Siswa Pada Mata Pelajaran IPA Materi Energi Bunyi Kelas IV Semester II di SDN I Sedayulawas Brondong Lamongan Tahun Pelajaran 2015/2016. JTIEE, Vol. 1, No. 1, h. 21-36, Mei 2017.

[15]Widhiatma, Y., \& Wasitohadi. 2017. Penerapan Model Problem Based Learning untuk Meningkatkan Hasil Belajar IPA Siswa Kelas 4 SDN Kalinanas 01. E-jurnal Mitra Pendidikan, Vol. 1, No. 4, h. 447-459, Juni 2017.

\section{Biografi Penulis Utama}

Penulis bernama lengkap "Shofi Wedhi Prayuda". Lahir di

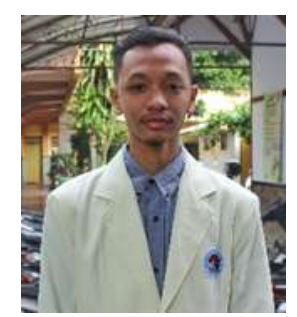
Kab. Semarang Jawa Tengah pada tanggal 18 September 1996 dari pasangan Kamdi dan Endang Trimahati. Penulis adalah anak kedua dari 3 bersaudara. Pendidikan sekolah dasar dimulai dari SD Negeri Karanganyar 01 Kec. Tuntang pada tahun 2002 - 2008. Setelah itu melanjutkan pendidikan sekolah menengah ke SMP Negeri 2 Bringin pada tahun 20082011 dan terakhir di SMA Negeri 1 Tuntang Kab. Semarang pada tahun 2011 - 2014. Selanjutnya melanjutkan pendidikan di perguruan tinggi mengambil jurusan Program Studi Pendidikan Guru Sekolah Dasar (PGSD), Fakultas Keguruan dan Ilmu Pendidikan (FKIP) di Universitas Kristen Satya Wacana Salatiga pada tahun 2014 sampai sekarang. Apabila ada kritik atau saran dapat dikirim ke alamat email penulis di: shofiwedhiprayuda1@gmail.com 